others, a conditlon probably due to wearlng boots Comparing the skiagram with that of a normal foot, there is seen to be a distinct, though slight, bowing of the metatarsal bones, the convexity belng outwards, and this is very marked in the toes, especially the fourth and fifth. A still more exaggerated degree of this is seen in the skeleton of the chimpanzee and gorilla. Its object is to facilitate apposition to the great toe and the grasping of objects In climbing.

The apes, too, walk entirely on the outer slde of the sole of the foot, and are not very agile in running. The deformity, whlch, as far as I know, is unique, is easlly explained by comparative anatomy, and is a reversion towards the condition met with among the higher apes.

\section{A NOTE ON}

DR. MILLIGAN'S PAPER, “THE TREATMENT OF CHRONIC SUPPURATION OF THE MIDDLE EAR WITHOUT RESORT TO RADICAL MASTOID OPERATION."

BY OSKAR KLOTZ, ASSISTANT PATHOLOGIST, ROYAL VICTORIA HOSPITAL, MONTREAL.

Dr. Milliana, in his paper in the British Mrdioal JOURNAL of October 12th, 1907, has brought forward many new polnts regarding the treatment of middle-ear disease whlch have their basis on the pathological findings of the exudate. The soundest treatment of medical and surgical cases has to-day its foundation on the pathological nature of the lesion, and, this being definitely determined, the physician's or surgeon's procedure is governed accordingly.

Dr. Milligan points out that the otologist must differentiate, before treatment is begun, the different stages of inflammations of the middle ear, and, further, the causative agent of the lesion must be ascertained. On the result of these findings depends the treatment of the case, and by this means unnecessary radical operations can be avolded and the prognosis can be given more accurately.

It is beyond my domain to discuss the different operative procedures, but there are some points in the conclusions that can be drawn Irom the examination of the inflammatory exudate whlch I wish to discuss.

I have had an opportunity, through the kindness of Dr. Birkett, of examining the exudates in middle-ear diseases. These cases were falr]y representative of the class that is met with in hospital practice. I would point out that in our experience the cases coming to the outdoor department of the Royal Victoria Hospital, Montreal, suffering from otitis media usually present a condition more chronic than those of the better classes met with in private practice; the latter class usually seek ald for middle-ear tronble earlier than the poorer classes. I have had the opportunity of examining material from cases in all stages of the disease.

Dr. Milligan points out that the inflammatory exudate varies with the stage of the disease, and that the exndates from these various stages have distlnct cellnlar characters, which may be recognlzed with the microscope. In the early acute stage there is "shedding of the superficlal columnar epithelial elements of the mucose, with lencocytes and red blood cells, and, "as chroniolty is established, the type of epithelium becomes changed to a more flattened and squamous variety, while leacocytes tend to be gradually replaced by lymphocrtes and myelocytes." He lays great stress on the cellalar character of the exudate, and adds:

Provided the oftological examination reveals an extensive leucocptosis, with, in addition degenerated columnar opileacocytosis, with, in addition, degenersted columnar epicome to is that the process is superficial, exudative, limited to come to is that the process is superticial, exudstive, limited to the mucosa, and capable of arrest by means of efficient local treatment. On the other hand, the presence of a number of mucosa, changes which suggest an extension of the inflammatory process lnto the deeper layers of the mucosa, and changes whiob are anlikely to be arrested by any form of purely local medioation.

Were we able to follow the course of an inflammatory process by the microscoplcal findings, particularly as regards the cellular contents of the exudate, the posslbilities of Dr. Milligan's findings would be Indeed. great.

It must be extremely rare to meet with such cases in whlch the eplthelial elements of the exudate can be recognized and differentiated. As these middle ear diseases are infective processes, where the invading agent attacks the tissues from within the ear cavities, the superficial mucosal cells are the first to be desquamated and destroyed. Not alone do the epithelial cells become shed; but, in consequence of the infecting agent, they become gwollen, granular, and frequently entirely broken up. To distinguish these cells from others, all will admit is Indeed difficult, but to distingulsh the various types of the epithelial elements among themselves is still more difficult.

In the exudates that I have had the opportunity of examining, and even among those in the early stage of middle-ear disease, I have not found the presence of recognizable epithelial cells in the stained preparations to be of definite significance. Where a purulent inflammatory exudate already exists, the superficial epithelial elements of the area involved in the ear must have been shed long before, and only those epithelial elements are likely to be involved which border the inflamed area. In these conditions, therefore, were it possible to distinguish the different kinds of epithelium, we would meet with both kinds of these epithelial cells, regardless of the stage or chronicity of the lesion.

Dr. Milligan also points out the variation in the leucocytes of the acute and chronic cases. In the former the polymorphonuclear leucocytes are the more numerous, while in the latter the lymphocytes are in the majority. This differentiation is probably possible where the chronic type refers to lesions advancing to healing, bat in those cases in which there is a long-standing greater or lese exudate, which clinlcally represents chronlcity, the exudate contalns polymorphonuclear leucocytes in greatest number. This is true whether the infiammation involves the soft tissues or even the bone. As Dr. Milligan further adds, the chronle cases are to a great extent mixed infections. This being so, these cases exhlbit not infrequent recurrent exacerbations of the disease as new infection is recelved. Moreover, in the socalled chronic cases it is but rarely seen that the entire lesion exhibits in all parts the same stage of the disease. We must therefore recognize that while healing is going. on in one area an acute or chronic inflammation mas exist at another, and have assoclated with it the acute Inflammatory leucocytes of the polymorphonuclear variety.

He diagnoses taberculous disease of the temporal bone by the presence of lymphocytes, epitheliold cells, myelo. cytes, and giant cells in the exudate. Fpithelioid cells, as they appear in the tubercles in the tissues, are not to be encountered in the exudate. Their form is entirely altered, and it would be difficult to distlnguish them from the wandering cells or fibroblasts seen in any healing wound. The most probable glant cells found in bone destruction of whatever origin are the osteoclasts. When we recall the great number of sputum analyses that are made, and the Infrequency. With which giant cells are found in those exudates from tuberculous infections, the evidence contributed by the presence or absence of these elements in exudate from the middle ear has but little value.

He also lays stress on the qualitative bacterial analyses, and In this we must agree. I believe that our best evidence of the nature of middle-ear disease lies in determining the kinds of orgenisms producing the lesions. In our experlence, the Microcoscus catarrhalis should not. be included among the virulent infectlons of the ear. The commonest dangerous organlem is the streptococcuis, while among the infrequent severe infectlous agents are the meningococci. I have not met with the gonococcus infection of the middle ear. Following this, in order of virulence and Irequency, are the pneumococcus, staphylococcus, $B$, influenzae, $B$. coli, $B$, typhi, B. pyocyaneus, and a number of other organlsms more rarely met with.

From my experience, I would conclude that much rellance cannot be placed on cytologlcal characters of the exndate, and that we must still look to the bacterio. logical examinations for our evidence as to the nature of the disease and its probable consequence. 